\title{
Corrections to: Fasciotomy Wound Management
}

\author{
Vasilios G. Igoumenou, Zinon T. Kokkalis, and Andreas F. Mavrogenis
}

\section{Correction to: \\ C. Mauffrey et al. (eds.), Compartment Syndrome, https://doi.org/10.1007/978-3-030-22331-1_9}

One of the author's family name had been missed out in the References section (\#1) in Chapter 9. This has now been corrected.

McLaughlin N, Heard H, Kelham S. Acute and chronic compartment syndromes: know when to act fast. JAAPA. 2014;27(6):23-6. https://doi.org/10.1097/01. JAA.0000446999.10176.13.

Open Access This chapter is licensed under the terms of the Creative Commons Attribution 4.0 International License (http://creativecommons.org/licenses/by/4.0/), which permits use, sharing, adaptation, distribution and reproduction in any medium or format, as long as you give appropriate credit to the original author(s) and the source, provide a link to the Creative Commons license and indicate if changes were made.

The images or other third party material in this chapter are included in the chapter's Creative Commons license, unless indicated otherwise in a credit line to the material. If material is not included in the chapter's Creative Commons license and your intended use is not permitted by statutory regulation or exceeds the permitted use, you will need to obtain permission directly from the copyright holder.

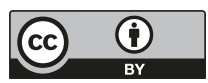

The updated online version of this chapter can be found at https://doi.org/10.1007/978-3-030-22331-1_9 